\title{
Hubungan Kecerdasan Intelektual Kecerdasan Emosional dan Kecerdasan Spiritual Terhadap Prestasi Belajar Fisika
}

\author{
Neneng Handriani ${ }^{1{ }^{*}}$, Muhammad Subhan ${ }^{2)}$ \\ ${ }^{1}$ Pasca sarjana Universitas Ahmad Dahlan \\ ${ }^{2}$ Prodi Fisika STKIP Bima \\ Email : neneng.handrianiphysics@gmail.com \\ d.hans2102@gmail.com
}

\begin{abstract}
ABSTRAK : Penelitian ini merupakan penelitian jenis ex-post facto yang memiliki tiga variabel bebas dan satu variabel terikat. Penelitian ini bertujuan untuk mengetahui (1) hubungan kecerdasan emosional terhadap prestasi belajar fisika siswa SMA Negeri 2 Kota Bima,(2) hubungan kecerdasan Intelektual terhadap prestasi belajar fisika siswa SMA Negeri 2 Kota Bima, (3) hubungan kecerdasan Spiritual terhadap prestasi belajar fisika siswa SMA Negeri 2 Kota Bima, (4) hubungan kecerdasan Emosional, kecerdasan intelektual terhadap kecerdasan Spiritual siswa SMA Negeri 2 Kota Bima. Pengambilan sampel dlakukan tekhnik random sampling, 6 kelas sebagai kelas sampel penelitian yaitu kelas XI IPA I sebanyak 6 orang siswa, XI IPA II sebanyak 5 orang siswa, XI IPA III sebanyak 5 orang siswa, XI IPA IV sebanyak 5 orang siswa, kelas XI IPA V sebanyak 5 orang siswa, dan XI IPA VI sebanyak 5 orang jadi jumlah sampelnya sebanyak 31 orang siswa.

Pengambilan data dilakukan dengan menggunakan angket kecerdasan Emosional, kecerdasan Intelektual, kecerdasan Spiritual dan dokumentasi berupa nilai raport. Dalam penelitian ini analisis data menunjukan bahwa: kuat hubungan kecerdasan Intektual, kecerdasan Emosional dan kecerdasan Spiriual terhadap prestasi belajar fisika siswa, hal ini dapat dilihat dari hasil uji hipotesis untuk ryx $x_{1}=0.994(99 \%), \operatorname{ryx}_{2}=0.981(98 \%)$ dan $\operatorname{ryx}_{3}=0.996$ (99\%) sehingga hubungan kecerdasan itelektual, emosional dan spiritual terhadap prestasi belajar siswa sangat kuat. Untuk mengetahui ada hubungan: (1) ada hubungan kecerdasan Intelektual terhadap prestasi belajar siswa penelitian yang diperoleh regresi linier sederhana (variabel $\mathrm{X}_{1}$ terhadap $\mathrm{Y}$ ) yang berbentuk $\mathrm{Y}=89,4772+(-$ 0,09).10, artinya persamaan tersebut dapat digunakan untuk menaksirkan harga $\mathrm{Y}$ jika $\mathrm{X}$ diketahui. Dari hasil perhitungan signifikansi diproleh pula $T_{\text {hitung }}$ lebih besar dari pada $T_{\text {tabel }}$ yaitu $T_{\text {hitung }}=27,401>F_{\text {tabel }}=2,042$. Ini membuktikan bahwa $\mathrm{Y}$ dipengaruhi oleh $\mathrm{X}_{1}$, (2) Ada pengaruh kecerdasan Emosional terhadap prestasi belajar fiska siswa, hal ini dapat dilihat dari analisis regresi linear sederhana ( variabel $\mathrm{X}_{2}$ terhadap $\mathrm{Y}$ ) yang berbentuk $\mathrm{Y}=$ $66,2013+0,228.10$, artinya persamaan tersebut dapat digunakan untuk menaksirkan hargaY jika X diketahui. Dari hasil perhitungan signifikansi diproleh pula $T_{\text {hitung }}$ lebih besar dari pada $T_{\text {tabel }}$ yaitu $T_{\text {hitung }}=47,048>F_{\text {tabel }}=2,042$. Ini membuktikan bahwa $\mathrm{Y}$ dipengaruhi juga oleh $\mathrm{X}_{2}$, (3) Ada pengaruh kecerdasan Spiritual terhadap prestasi belajar fisika siswa, hal ini dapat dilihat dari analisis Regresi linier sederhana (variabel $\mathrm{X}_{3}$ terhadap $\mathrm{Y}$ ) yang berbentuk $\mathrm{Y}=72,0066+0,123,10$ artinya persamaan tersebut dapat digunakan untuk menaksirkan harga $\mathrm{Y}$ jika $\mathrm{X}$ diketahui. Dari hasil perhitungan signifikansi diproleh pula $\mathrm{T}_{\text {hitung }}$ lebih besar dari pada $\mathrm{T}_{\text {tabel }}$ yaitu $\mathrm{T}_{\text {hitung }}=57,344$ > $\mathrm{T}_{\text {tabel }}=2,042$. Ini membuktikan bahwa $\mathrm{Y}$ dipengaruhi juga oleh $\mathrm{X}_{3}$, (4) Ada pengaruh kecerdasan Intelektual, kecerdasan Emosional dan kecerdasan spiritual terhadap prestasi belajar fisika siswa, hal ini dapat dilihat dari analisis regresi linier parsial (variabel $\mathrm{X}_{1}, \mathrm{X}_{2}$ dan $\mathrm{X}_{3}$ terhadap $\mathrm{Y}$ ) yang berbentuk $\mathrm{Y}=0,981-0,994+0,996$ menunjukan besarnya pengaruh antara variabel $\mathrm{X}_{1}, \mathrm{X}_{2}$ dan variabel $\mathrm{X}_{3}$ terhadap $\mathrm{Y}$. Koofisien determinan $\mathrm{KP}=$ 0,99, dari perhitungan memberikan arti bahwa besarnya pengaruh kecerdasan Emosional, kecerdasan Intelektual dan kecerdasan Spiritual terhadap prestasi belajar fisika siswa adalah 0,99 atau 99\%. Dengan demikian hipotesis Ho ditolak dan hipotesis Ha diterima. Sedemikian sehingga ketiga hipotesis dalam penelitian ini terbukti kebenarannya.
\end{abstract}

Kata kunci: Kecerdasan emosional, Kecerdasan Intelektual, Kecerdasan Spiritual, Prestasi Belajar fisika

\section{PENDAHULUAN DAN KAJIAN LITERATUR}

Ilmu pengetahuan terbentuk atas landasan berfikir manusia dalam artian bahwa ilmu pengetahuan berfungsi sebagai sarana berpikir ilmiah dan untuk menumbuhkembangkan kemampuan berpikir logis dikalangan siswa. Fisika merupakan bagian dari Ilmu 
pengetahuan yang dibangun atas dasar teori yang mebutuhkan kemampuan berpikir manusia untuk dapat memahami sifat alam dan gejala-gejala fisis sehingga terbetuk berbagai klasifikasi konsep fisika. Dalam memahami konsep fisika membutuhkan keterampilan khusus seperti menguasai cara perumusan persamaan ataupun hitungan, sehingga tidak semua orang yang memiki kecerdasan mampu memahami konsep fisika, akan tetapi orang yang mampu memahami sebagian besar konsep-konsep fisika diindentikkan orang cerdas.

Kecerdasan senantiasa diidentikkan dengan Kecerdasan Intelektual atau yang lazim dikenal sebagai IQ (Intelligence Quotient). Namun pada saat ini, anggapan bahwa kecerdasan manusia hanya tertumpu pada dimensi intelektual saja sudah tidak berlaku lagi. Sebab IQ manusia juga masih memiliki dimensi kecerdasan lainnya yaitu : Kecerdasan Emosional atau EQ (Emotional Quotient) dan Kecerdasan Spiritual atau SQ (Spiritual Quotient).

Kecerdasan Emosional atau EQ adalah mengukur kemampuan seseorang dari aspek pengendalian dan pengembangan emosi. Sedangkan menurut Danah Zohar dan Ian Marshall kecerdasan Spiritual merupakan landasan yang diperlukan untuk memfungsikan kecerdasan intelektual dan kecerdasan emosional secara efektif dalam [1]

Kecerdasan manusia ternyata lebih luas dari anggapan yang dianut selama ini. Kecerdasan manusia bukanlah merupakan suatu hal yang bersifat dimensi tunggal semata, yang hanya bisa diukur dari satu sisi dimensi saja (dimensi IQ). Kesuksesan manusia dan juga kebahagiaannya, ternyata lebih terkait dengan beberapa jenis kecerdasan selain IQ. Kecerdasan spiritual memungkinkan peserta didik menjadi kreatif, kemampuan membudayakan, memberi rasa moral, dan memberikan makna positif. Kecerdasan spiritual mengintegrasikan semua kecerdasan kita. Kecerdasan spiritual menjadikan kita makhluk yang benar-benar utuh secara intelektual, emosional dan spiritual.

IQ merupakan suatu kecerdasan yang berkaitan dengan kesadaran akan ruang, kesadaran akan suatu yang tampak dan penguasaan matematika. Dengan kecerdasan ini manusia mampu menghitung, belajar aljabar, mengoperasikan computer, belajar bahasan asing, memahami rumus-rumus fisika maupun melakukan perhitungan yang rumit sekalipun [2].

Kecerdasan intelektual merupakan kemampuan individu untuk menghadapi tuntutan kehidupan, dan berhubungan dengan keahlian dalam berfikir skala normal dan rasio. Berdasarkan uraian di atas dapat disimpulkan bahwa kecerdasan intelektual merupakan kemampuan seseorang untuk melakukan segala hal secara sistematis dengan melihat kondisi secara menyeluruh.

Danah Zohar dan Ian Marshall mendefinisikan kecerdasan spiritual sebagai kecerdasan untuk menghadapi persoalan makna yaitu kecerdasan untuk menempatkan prilaku dan hidup kita dalam konteks makna yang lebih luas dan kaya, kecerdasan untuk menilai bahwa tindakan atau jalan hidup seseorang lebih bermakna dibandingkan dengan yang lain. [3]

Spiritual Quotient (SQ) adalah kecerdasan yang berperan sebagai landasan yang diperlukan untuk memfungsikan IQ dan EQ secara efektif. Oleh karena itu, kecerdasan spiritual juga dikatakan sebagai kecerdasan tertinggi dalam diri kita. Dari pernyataan tersebut, kecerdasan spiritual saja tidak dapat menyelesaikan masalah, sehingga diperlukan keseimbangan pula dari kecerdasan emosi dan kecerdasan intelektualnya. Jadi, seharusnya IQ, EQ dan SQ pada diri setiap orang mampu secara proporsional bersinergi, menghasilkan kekuatan jiwa raga yang penuh keseimbangan.

Kecerdasan spiritual merupakan landasan untuk memfungsikan kecerdasan intelektual dan kecerdasan emosional. Seseorang yang mampu menyeimbangkan antara ketiga kecerdasan tersebut akan mampu berprestasi tinggi. Dalam hubungannya dengan pencapaian pembelajaran penguasaan fisika dimana indikator kecerdasan emosional yaitu kemampuan memotivasi akan memberikan dorongan untuk senantiasa berprestasi, memiliki komitmen, inisiatif dan optimis. Keterampilan sosial memberikan siswa kemampuan untuk membangun komunikasi dengan berbagai pihak. Siswa yang memiliki kemampuan tersebut akan senantiasa menjalin kerja sama dengan rekan-rekannya untuk memecahkan soal-soal fisika yang diberikan dan tidak segan-segan bertanya kepada guru manakala ada persoalan yang tidak dapat dipecahkan sendiri. Dengan demikian, kemampuan memotivasi dan keterampilan sosial akan memberikan pengaruh yang positif terhadap hasil belajar fisika siswa.

Kecerdasan intelektual dalam hubungannya dengan pembelajaran fisika akan memberikan pengaruh dari cara siswa mengeluarkan nalar yang telah di rangkaikan dalam pikirannya yang berisikan penyatuan kata yang sistematis sesuai dengan yang sedang ia hadapi sehingga dari caranya memaparkan dari pada pendapatnya tersebut membantu siswa lain untuk lebih mengerti arah pembelajaran fisika.

Kecerdasan spiritual dalam hubungannya dengan pembelajaran fisika akan memberikan perasaan bahagia dan senang ketika mempelajari fisika karena seseorang siswa yang memiliki kecerdasan spiritual yang tinggi dapat menemukan makna positif yang terkandung dalam ilmu fisika yang terkait terhadap pengalaman dalam kehidupan 
sehari-hari baik yang berhubungan dengan peraturan alam semesta, kedisiplinan, kejujuran, dan lain-lain.

Demikian pula salah satu indikator kecerdasan spiritual yaitu sabar terhadap kesulitan sangat dibutuhkan dalam mempelajari ilmu fisika karena ilmu fisika dipelajari haruslah dengan bertahap yaitu mempelajari konsep B berdasarkan pada konsep A seseorang perlu memahami konsep A terlebih dahulu. Tanpa memahami konsep A, tidak mungkin orang itu memahami konsep B. ini berarti mempelajari fisika diperlukan kesabaran untuk menguasai pengalaman belajar yang lalu untuk menuju tahap yang berikutnya.

Dengan demikian, manakala seorang siswa memiliki kecerdasan emosional, kecerdasan intelektual dan kecerdasan spiritual yang baik, ketiganya akan saling bersinergi dalam mencapai prestasi belajar yang gemilang

\section{METODE PENELITIAN}

Dalam penelitian ini akan diselidiki hubungan antara variabel bebas dan variabel terikat. Hubungan antara variabel-variabel tersebut dapat digambarkan sebagai berikut

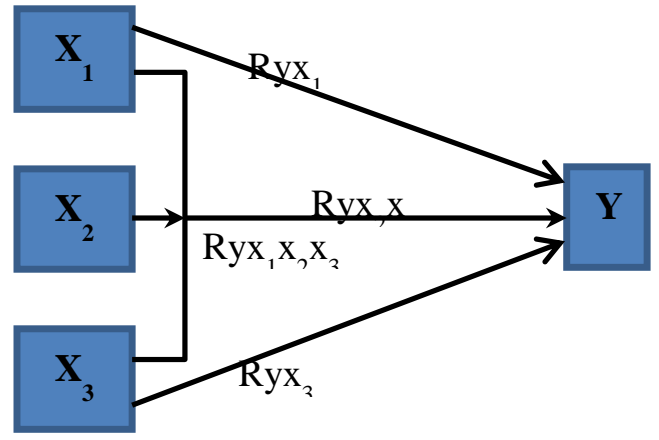

Gambar 1 hubungan antara variabel penelitian
Keterangan :
Y : Prestasi belajar fisika
$\mathrm{X} 1$ : Kecerdasan intelektual
$\mathrm{X} 2$ : Kecerdasan emosional
X3: kecerdasan spiritual

[4]

Prosedur pengambilan sampel pada penelitian ini adalah menggunakan tekhnik proporsi random sampling yaitu sampel acak dengan cara undian, Karena seluruh populasi memiliki kesempatan yang sama untuk dijadikan sampel penelitian. Dari prosedur ini, maka sesuai dengan jumlah seluruh siswa kelas XI IPA SMA Negeri 2 Kota Bima adalah sebanyak 155 siswa, kemudian peneliti mengambil $20 \%$ dari jumlah populasi tersebut sehingga jumlah sampel yang akan diteliti adalah sebanyak $155 \mathrm{x}$ $20 \%=3100 / 100=31$ siswa
Instrumen adalah suatu cara yang dapat digunakan untuk mengumpulkan data dengan sebaik-baiknya. Dengan demikian metode pengumpulan data dalam penelitian ini adalah metode angket (koesioner) dan dokumentasi.

Teknik pengumpulan data yang dilakukan adalah dengan memberikan instrumen (alat pengumpul data) kepada responden. Pada saat pengambilan data, diamati langsung oleh peneliti bersama guru bidang studi fisika dengan demikian responden dapat menanyakan langsung kepada peneliti hal-hal yang kurang jelas sehubungan dengan petunjuk pengisian instrumen yang diberikan.

Teknik analisis data digunakan adalah dengan mengguna uji korelasi asosiasif antar variabel kemudian dilanjutkan ke uji korelasi parsial dikarenakan variable $\mathrm{x}$ lebih dari satu dan diakhiri dengan uji hipotesis. Adapun persamaan yang digunakan adalah sebagai berikut:

$$
r_{x y}=\frac{\sum x y}{\sqrt{\left(\sum x^{2}\right)\left(\sum y^{2}\right)}}
$$

Tabel 1. Pedoman koefisien korelasi :

\begin{tabular}{cc}
\hline $\begin{array}{c}\text { Interval } \\
\text { korelasi }\end{array}$ & $\begin{array}{c}\text { Tingkat } \\
\text { hubungan }\end{array}$ \\
\hline $0,00-0,199$ & Sangat rendah \\
$0,20-0,39$ & Rendah \\
$0,40-0,59$ & Sedang \\
$0,60-0,799$ & Kuat \\
$0,80-1,000$ & Sangat kuat \\
\hline
\end{tabular}

sedangkan untuk pengujian statistik korelasi parsial lebih dari 2 variabel $\mathrm{X}_{1}, \mathrm{X}_{2}, \mathrm{X}_{3}, \mathrm{Y}$ digunakan rumus :

$$
r_{y, x_{1}, x_{2} \ldots x_{i}}=\sqrt{\frac{b_{1} \cdot \sum x_{1} y+b_{2} \cdot \sum x_{2} y+\ldots+b_{i} \cdot \sum x_{i} y}{\Sigma y^{2}}}
$$

Kemudian menghitung dengan rumus uji t:

$$
t=\frac{r \sqrt{n-4}}{\sqrt{1-r^{2}}}
$$

\section{HASIL DAN PEMBAHASAN}

a. Tabel 2. Nilai raport fisika siswa kelas XI IPA SMA Negeri 2 Kota Bima

\begin{tabular}{ccc}
\hline \multicolumn{1}{c}{ No } & Nila & Frek \\
\hline $\mathbf{1}$ & 70 & 1 \\
$\mathbf{2}$ & 75 & 2 \\
$\mathbf{3}$ & 78 & 1 \\
$\mathbf{4}$ & 80 & 9 \\
$\mathbf{5}$ & 85 & 8 \\
$\mathbf{6}$ & 87 & 6 \\
$\mathbf{7}$ & 88 & 2 \\
$\mathbf{8}$ & 90 & 2 \\
Jumlah & \multicolumn{2}{c}{31} \\
Rerata & \multicolumn{2}{c}{83,1} \\
max & \multicolumn{2}{c}{90} \\
\hline min & \multicolumn{2}{c}{70} \\
\hline
\end{tabular}




\section{b. Uji Korelasi}

Mencari nilai korelasi $\mathrm{X}$ dan $\mathrm{Y}$. Hasil perhitungan korelasi $\mathrm{X}_{1} \mathrm{Y}, \mathrm{X}_{2} \mathrm{Y}$ dan $\mathrm{X}_{3} \mathrm{Y}$ didapat hasil pada tabel di bawa ini :

Tabel 3. uji korelasi

\begin{tabular}{llll}
\hline \multicolumn{2}{c}{$\mathbf{R}_{\text {hitung }}$} & $\mathbf{R}^{\mathbf{2}}$ & $\mathbf{R}_{\text {tabel }}$ \\
\hline $\mathbf{r y x}_{\mathbf{1}}$ & 0.983 & 0,96 & \\
$\mathbf{r y x}_{\mathbf{2}}$ & 0.993 & 0,93 & 0,355 \\
$\mathbf{r y x}_{\mathbf{3}}$ & 0.996 & 0,99 & \\
\hline
\end{tabular}

Table 4. Uji korelasi parsial $\mathrm{X}_{1} \mathrm{X}_{2} \mathrm{X}_{3}$ dan $\mathrm{Y}$

\begin{tabular}{cc}
\hline $\mathbf{R}_{\text {hitung }}$ & $\begin{array}{c}\mathbf{R}_{\text {tabel }} \\
\text { Signifikan (0,05) }\end{array}$ \\
\hline 0,349 & 0,355 \\
\hline
\end{tabular}

c. Uji Hipotesis

Table 5 Uji hipotesis antar variable dan parsial

\begin{tabular}{crrr}
\hline No & \multicolumn{2}{c}{$\mathbf{t}_{\text {hitung }}$} & $\mathbf{t}_{\text {Tabel }}$ \\
\hline $\mathbf{1}$ & $\mathrm{tx}_{1} \mathrm{y}=$ & 28,89 & \\
$\mathbf{2}$ & $\mathrm{tx}_{2} \mathrm{y}=$ & 44,42 & \\
$\mathbf{3}$ & $\mathrm{tx}_{3} \mathrm{y}=$ & 57.34 & 2.042 \\
$\mathbf{4}$ & $\mathrm{t}_{\text {parsial }}=$ & $\mathbf{2 . 4 9 6 6}$ & \\
\hline
\end{tabular}

Table di atas menjelaskan bahwa didapatkan $r_{\text {hitung }}$ sebesar 0,349. Dengan koefisien korelasi tersebut selanjutnya diuji signifikansinya dengan membandingkan $\mathrm{r}_{\text {tabel }} \cdot \mathrm{r}_{\text {tabel }}$ untuk $\mathrm{n}=31$ dan kesalahan $5 \%$ maka $\mathrm{r}_{\text {tabel }}=0,355$ sedangkan $r_{\text {hitung }}$ adalah 0,349. Dari hasil tampak bahwa $r_{\text {hitung }}$ lebih besar dari $r_{\text {tabel }}$ maka Ha diterima, dengan demikian korelasi 0,433 itu signifikan. Maka hipotesis yang mengatakan terdapat hubungan Kecerdasan Emosional, Kecerdasan Intelektual dan Kecerdasan Spiritual terhadap prestasi belajar siswa SMA kelas VI dapat diterima. Dilakukan uji determin menghasilkan hubungan kecerdasan Intelektual terhadap prestasi belajar sangat kuat yaitu 99\%, hubungan kecerdasan Emosional terhadap prestasi belajar sangat kuat yaitu $96 \%$ dan hubungan kecerdasan Spiritual terhadap prestasi belajar sangat kuat yaitu $99 \%$.

\section{KESIMPULAN}

Untuk kecerdasan intelektual ditinjau secara keseluruhan item angket yang tergolong tinggi dimana 90,32\% siswa menjawab seluruh item angket dengan baik dan 9,68\% tergolong kategori rendah. Dan tingkat kecerdasan Emosional siswa ditinjau secara keseluruhan item angket tergolong kategori tinggi dimana $96,77 \%$ siswa menjawab seluruh item angket dengan baik dan 3,23\% tergolong kategori rendah. Dan untuk kecerdasan intelektual ditinjau secara keseluruhan item angket yang tergolong tinggi dimana 90,32\% siswa menjawab seluruh item angket dengan baik dan 9,68\% tergolong kategori rendah. Sedangkan tingkat kecerdasan Spiritual siswa ditinjau secara keseluruhan item angket tergolong kedalam kategori tinggi dimana $100 \%$ siswa menjawab seluruh item angket dengan baik dan $0 \%$ tergolong kategori rendah karena angket berisi pernyata'an positif. Hal ini menunjukan bahwa siswa memiliki tingkat kecerdasan Spiritual tinggi sedangkan kecerdasan Intelektual dan Emosional berada dibawah nilai kecerdasan Spiritual. Berdasarkan hasil analisis data korelasi antara kecerdasan Emosional, kecerdasan Intelektual dan kecerdasan Spiriual terhadap prestasi belajar fisika bahwa terdapat hubungan kecerdasan Intelektual, kecedasan Emosional dan kecerdasan Spiritual terhadap prestasi belajar fisika siswa kelas XI IPA SMA Negeri 2 Kota Bima

\section{DAFTAR PUSTAKA}

[1],[3] Hanifa, Ifa M. 2005. Antara IQ, EQ dan $S Q$ : jurnal Ginanjar, 2003. ESQ Power: Jakarta: Arga

[4] Sugiyono, 2011. Metode penelitian kuantitatif kualitati dan $R \& D$.Bandung: alfabeta 